\title{
Phosphate availability controls Trichodesmium spp. biomass in the SW Pacific Ocean
}

\author{
Thierry Moutin ${ }^{1, *}$, Nathalie Van Den Broeck ${ }^{1}$, Beatriz Beker ${ }^{1}$, Cécile Dupouy ${ }^{2}$, \\ Peggy Rimmelin ${ }^{1}$, Aubert Le Bouteiller ${ }^{2}$ \\ ${ }^{1}$ Laboratoire d'Océanographie et de Biogéochimie (UMR 6535), Centre d'Océanologie de Marseille, Campus de Luminy, \\ 13288 Marseille Cedex 09, France \\ ${ }^{2}$ Institut de Recherche pour le Développement (IRD), BP A5, 98848 Nouméa, New Caledonia
}

\begin{abstract}
Throughout tropical and subtropical seas, Trichodesmium spp. contribute significantly to marine fixation of atmospheric di-nitrogen and influence the global carbon cycle. We suggest that dissolved inorganic phosphate (DIP) availability has a predominant role in controlling Trichodesmium spp. biomass. From experimental work carried out on cruises in the SW Pacific Ocean, and by re-analysing previous data, we have defined a critical level of DIP needed for single filaments of Trichodesmium spp. to grow. Thus, seasonal variations in DIP availability could control Trichodesmium spp. growth and decay. As this critical level is below the detection limit of classical DIP measurements obtained during oceanic cruises, we suggest a re-evaluation of the phosphate availability in the oligotrophic ocean in order to determine what ultimately controls di-nitrogen fixation in the sea.
\end{abstract}

KEY WORDS: Trichodesmium spp. · Phosphate availability · Diazotrophy · South Pacific Ocean

\section{INTRODUCTION}

In a nitrogen-limited ocean, the input of 'new' nitrogen (i.e. not related to organic matter recycling) into the photic zone controls primary production (Codispoti 1989). Nitrogen fixation in the ocean is a source of new nitrogen. Thus, a fundamental question arises as to what factors control nitrogen fixation in the ocean. What are the factors that control $\mathrm{N}_{2}$ fixation over annual or longer time-scales (Falkowski 1997, Letelier \& Karl 1998, Tyrell 1999) and are these distinct from 'physiological' factors that may temporarily control the process of nitrogen fixation? Light, temperature (Carpenter et al. 2004) and nutrient availability, particularly that of phosphate (Sañudo-Wilhelmy et al. 2001, Mulholland et al. 2002, Fu \& Bell 2003) and iron (Behrenfeld \& Kobler 1999, Kustka et al. 2002), could physiologically control the kinetics of nitrogen fixation. These factors could be different from the 'systemic' factor (Paasche \& Erga 1988) that controls the cumulative biomass over time within a particular oceanic area, and ultimately, when considering all the oceanic provinces, the amount of nitrogen introduced via dinitrogen fixation in the world's oceans.

Physiological factors can be investigated using short-term experiments such as selective enrichment experiments showing that there may be co-limitation of diazotrophs by both iron and dissolved inorganic phosphate (DIP) in certain situations (Mills et al. 2004). However, such short-term limitation may not control accumulation of diazotroph biomass over time. For example, if the systemic limiting factor is DIP availability in a particular area, a more or less high iron availability will only drive the system to a more or less rapid consumption of DIP. The cumulative biomass of Trichodesmium spp., which depends essentially on the DIP consumption, will not be affected in the long term by iron availability. Considering the cumulative biomass as the end product of the nitrogen fixation process, 'physiological' factors act as catalytic factors only. Thus, knowing the systemic controlling factor is of prime necessity and can only be assessed 
using annual or longer-term studies on nutrient availability and uptake kinetics parameters of the species studied.

We studied DIP availability and the response of the DIP uptake system of natural Trichodesmium spp. populations to increasing DIP concentrations. The work was carried out in the SW Pacific Ocean near New Caledonia, an area where Trichodesmium spp. blooms are frequently observed (Dupouy et al. 2000). Using kinetic experiments, we determined the critical DIP concentration for Trichodesmium spp. growth. We then provide further evidence correlating annual patterns of the observed surface accumulations of Trichodesmium spp., with decreasing ambient DIP availability. Our results suggest that DIP is the systemic $\mathrm{N}_{2}$ fixation limiting nutrient in this area.

\section{MATERIALS AND METHODS}

Surface water samples and Trichodesmium spp. were collected on the RV 'L'Alis' from 5 to 12 February 2003 in the open SW Pacific Ocean east of New Caledonia (Diapalis Cruise 7 of the DIAPAZON program: DIAzotrophic PAcific ZONe; $20-22^{\circ} \mathrm{S}$ latitude, $166-168^{\circ} \mathrm{E}$ longitude). Kinetic experiments were carried out on concentrated Trichodesmium spp. samples collected using $35 \mu \mathrm{m}$ mesh nets and on unconcentrated samples.

Kinetics from Trichodesmium spp. collected in nets (Expts MT [a] and MT [b]). The net tows were performed at the stations from a depth of $1 \mathrm{~m}$. The net was slowly lowered and raised 10 times in $10 \mathrm{~min}$. Net tow material $(200 \mathrm{ml})$ was mixed with $800 \mathrm{ml}$ of $0.2 \mu \mathrm{m}$ filtered seawater by slow agitation and subsamples were immediately taken up for chemical and biological analyses.

DIP was estimated immediately with the molybdenum blue reaction (Strickland \& Parsons 1972) on $50 \mathrm{ml}$ samples using a $10 \mathrm{~cm}$ path length cell in a Cecil CE 1011 spectrophotometer. Particulate phosphate (PP) was determined following filtration of $50 \mathrm{ml}$ samples through polycarbonate filters $(10 \mu \mathrm{m} ; 4 \mathrm{~mm})$ using the standard DIP analysis of high temperature persulfate wet-oxidation at $120^{\circ} \mathrm{C}$ and 1 bar (Pujo-Pay \& Raimbault 1994). Total phosphate (TP) was estimated on $40 \mathrm{ml}$ samples following the same wet-oxidation as for PP. Dissolved organic phosphate: $[\mathrm{DOP}]=[\mathrm{TP}]-[\mathrm{DIP}]-$ [PP].

Biovolumes of Trichodesmium spp. and other phytoplankters were estimated with an inverted microscope (Wild M40) using Utermöhl settling chambers (2 ml) from samples fixed with Lugols. Organisms were identified to the species level (trichome width for Trichodesmium). Estimates of cell volume for each species (organisms > $5 \mu \mathrm{m}$ length) were obtained using measurements from 30 to 50 cells for each species and the application of the geometric formula best fitted to the cell shape (Hillebrand et al. 1999) with estimation of the parietal cytoplasm thickness (Smayda 1978).

DIP uptake was measured from $50 \mathrm{ml}$ samples incubated with $185 \mathrm{kBq}\left(5 \mu \mathrm{Ci}\right.$ ) carrier-free ${ }^{33} \mathrm{PO}_{4}$ (Amersham BF1003) in polycarbonate vials using an on-deck incubator at sea surface temperature. Incubations $(t=$ $1 \mathrm{~h}$ ) were stopped by the addition of $500 \mu \mathrm{l}$ of $10 \mathrm{mM}$ non-radioactive $\mathrm{KH}_{2} \mathrm{PO}_{4}$ and samples were filtered immediately onto $10 \mu \mathrm{m}$ (25 mm diameter) polycarbonate filters. Radioactivity on the filters (cpm) was measured using scintillation liquid counting and the specific uptake rate $V\left(\mathrm{~h}^{-1}\right)$ was calculated from the equation:

$$
V_{\text {sp. }}=\left\{\left[\left(R_{\mathrm{f}}-R_{\mathrm{b}}\right) / R_{\mathrm{t}}\right] \times \mathrm{DIP}\right\} /(t \times \mathrm{PP})
$$

where $R_{\mathrm{f}}, R_{\mathrm{b}}$, and $R_{\mathrm{t}}$ are the radioactivity of the filter, the blank (fixed with ca. $100 \mu \mathrm{l}$ of $20 \mathrm{~g} \mathrm{l}^{-1} \mathrm{HgCl}_{2}$ ), and the total tracer added to the sample. DIP is the initial plus the added DIP concentrations (0 to $300 \mu \mathrm{l}$ of a $100 \mu \mathrm{M} \mathrm{KH} \mathrm{PO}_{4}$ solution). PP and $t$ are the particulate phosphate concentration and the incubation time, respectively. The maximum value of the blank was $2.3 \%$ of the filter activity. A time-course experiment conducted for DIP uptake (data not shown) indicated no significant difference in the rates between $5 \mathrm{~min}$ and $2 \mathrm{~h}$ of incubation time.

Kinetics using unconcentrated samples (E). The same protocol as for concentrated Trichodesmium spp. was followed for samples collected with a Niskin bottle in the upper surface water. In order to take into account the lower biomass concentrations (no preconcentration), $1000 \mathrm{ml}$ of water was processed for PP determination. The incubation time for the measurement of DIP uptake was increased to $1.5 \mathrm{~h}$ and $25 \mathrm{ml}$ was processed for biomass estimations.

Seasonal variations of phosphate availability. Seasonal variations were determined using data from Cruises 1 to 6, see Van Den Broeck et al. (2004) for details on methods, particularly DIP turnover times $\left(\mathrm{T}_{\mathrm{DIP}}\right)$ measurements, and sampling strategy.

\section{RESULTS}

\section{Critical DIP availability for Trichodesmium spp. growth}

Dissolved inorganic, organic, and particulate phosphate (DIP, DOP and PP) concentrations are presented along with Trichodesmium spp. and other phytoplanktonic biomasses (Table 1). As expected in samples 
Table 1. Initial concentrations of dissolved inorganic phosphate (DIP), particulate phosphate (PP), total phosphate (TP), dissolved organic phosphate (DOP) and biomasses of Trichodesmium spp. and other phytoplanktonic species for the kinetic experiments from Trichodesmium spp. collected with a net (MT(a) and MT(b)) and unconcentrated samples (E). Data are mean \pm SD with no. of samples in parentheses, where shown. ; indicates duplicate values

\begin{tabular}{|ccccccc|}
\hline & $\begin{array}{c}\text { DIP } \\
(\mathrm{nM})\end{array}$ & $\begin{array}{c}\text { PP } \\
(\mathrm{nM})\end{array}$ & $\begin{array}{c}\text { TP } \\
(\mathrm{nM})\end{array}$ & $\begin{array}{c}\text { DOP } \\
(\mathrm{nM})\end{array}$ & Trichodesmium & $\begin{array}{c}\text { Biomass }\left(10^{9} \mu^{3} \mathrm{l}^{-1}\right) \\
\text { Other Phyto. spp. }>5 \mu \mathrm{m}\end{array}$ \\
\hline MT (a) & $247 \pm 20(3)$ & $322 \pm 26(3)$ & $1158 ; 1064$ & 542 & $1.92 ; 2.50$ & $0.08 ; 0.08$ \\
MT (b) & $177 \pm 40(3)$ & $365 \pm 78(3)$ & $1005 \pm 70(3)$ & 463 & $7.24 ; 7.28$ & $0.07 ; 0.01$ \\
(E) & $20 ; 20$ & 20.4 & $397 \pm 12(3)$ & 357 & 0.41 & 0.01 \\
\hline
\end{tabular}

using net tow material, PP and biomass increased. DOP concentrations increased slightly while DIP concentrations exhibited a large increase possibly related to excretion by zooplankton in the net tow material. Experiments were also carried out, for the first time, on unconcentrated samples rich in Trichodesmium spp. that had low initial DIP concentrations. Trichodesmium spp. represented at least $95 \%$ of the phytoplanktonic biomass estimated by cell volumes, and appeared as single 'filaments' (or trichomes) only.

The specific uptake rate versus concentration curve (Fig. 1) shows a saturation curve. Michaelis-Menten parameters obtained following the Marquardt-Levenberg minimisation calculation with 4 iterations gives $K_{\mathrm{s}}=630 \mathrm{nM}(\mathrm{SD}=133)$ and $V_{\text {max sp. }}=0.31 \mathrm{~h}^{-1}(\mathrm{SD}=$ $0.04)$. The substrate [DIP] varies from 0.03 to 1.23 of the $K_{\mathrm{s}}$ value and $V_{\text {sp. }}$ varies from 0.03 to 0.52 of the $V_{\max }$ sp. value. This is the first recorded estimate of $K_{\mathrm{s}}$ for

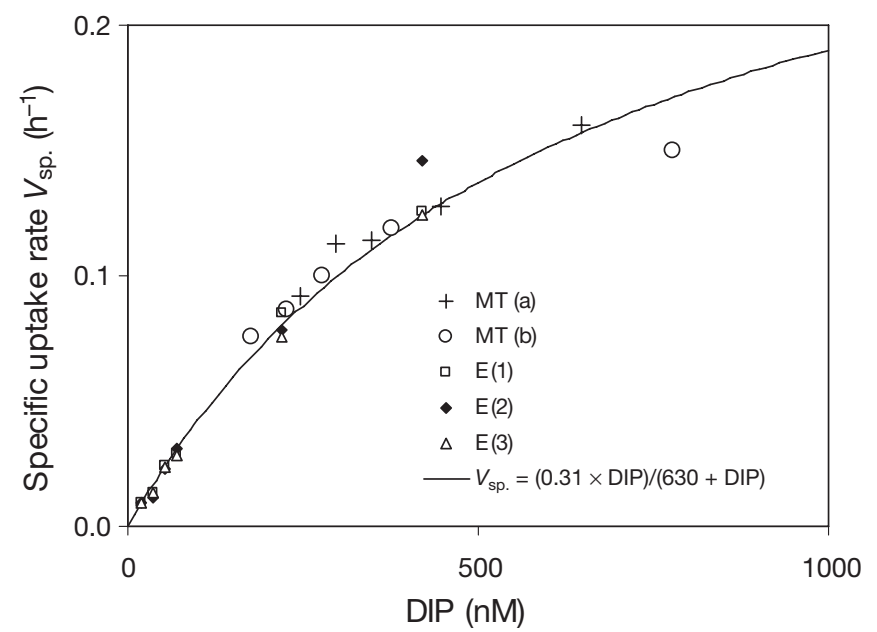

Fig. 1. Dissolved inorganic phosphate (DIP) specific uptake rate by natural populations of Trichodesmium spp. versus DIP concentration. Experiments conducted in February 2003 (Diapalis Cruise 7, SW Pacific Ocean near New Caledonia) from net-collected Trichodesmium spp. (MT(a): +; MT(b): o) and from unconcentrated samples in triplicates $\left(E(1): \square_{;} E(2)\right.$ : - E(3): $\Delta$ ). Theoretical curve using Michaelis-Menten parameters obtained following the Marquardt-Levenberg minimization: $K_{\mathrm{s}}=630 \mathrm{nM}$ and $V_{\max s p}=0.31 \mathrm{~h}^{-1}$
Trichodesmium spp. at environmentally significant concentrations. The $V_{\max }$ value was only reached at concentrations greater than the maximum concentration already measured in the upper water column in this area (DIP $=120 \mathrm{nM}$ ). Interestingly, similar specific uptake rates were measured with and without pre-concentrating Trichodesmium spp. A decrease in uptake rates following brief exposure to high DIP concentrations might be expected, but was not observed.

From the Michaelis-Menten relationship, we calculated the time required for the Trichodesmium spp. biomass to double constituent $\mathrm{P}\left(t_{\mathrm{d}}\right), t_{\mathrm{d}}=\ln 2 /\left(24 V_{\mathrm{sp}}\right)$, (Table 2), assuming growth in a exponential phase, no excretion, and DIP as the only source of phosphate. The $t_{\mathrm{d}}$ range is calculated using an upper limit of $50 \%$ positive or negative variation in the $V_{\text {sp. }}$ estimates. The 1 to $100 \mathrm{nM}$ range of DIP concentration corresponds to the variations in seasonal DIP concentrations observed in the upper surface water of this area (Van Den Broeck et al. 2004). These in situ concentrations were measured by the classical colorimetric method (Detection limit: $\mathrm{DL}=30 \mathrm{nM}$ ) and by an indirect method (DL = $2 \mathrm{pM}$ ) based on turnover times when DIP reached undetectable levels (DIP $=\mathrm{T}_{\mathrm{DIP}} \times$ DIP uptake). DIP uptake was derived from primary and bacterial productions using C:P ratios. Given the high accuracy of turnover time measurements, the natural variability in the C:P uptake ratios did not affect the order of magni-

Table 2. Dissolved inorganic phosphate (DIP), specific uptake rates $\left(V_{\mathrm{sp}}\right)$ and time required to double constituent $\mathrm{P}\left(t_{\mathrm{d}}\right.$, in parentheses $t_{\mathrm{d}}$ calculated with $V_{\mathrm{sp}} \pm 50 \%$ ) for DIP concentrations in the range encountered during our observations in the open SW Pacific Ocean near New Caledonia (Diapalis cruises)

\begin{tabular}{|ccc|}
\hline DIP (nM) & $V_{\text {sp. }}\left(\mathrm{h}^{-1}\right)$ & $t_{\mathrm{d}}(\mathrm{d})$ \\
\hline 1 & 0.0005 & $59(39-118)$ \\
10 & 0.0048 & $6.0(4.0-11.9)$ \\
30 & 0.0141 & $2.0(1.4-4.1)$ \\
50 & 0.0228 & $1.3(0.8-2.5)$ \\
100 & 0.0425 & $0.7(0.5-1.4)$ \\
\hline
\end{tabular}


tude of the calculated concentrations and allowed us to reach a sub-nanomolar detection limit (Moutin et al. 2002, Van Den Broeck et al. 2004).

The $t_{\mathrm{d}}$ values varied from 0.7 to $59 \mathrm{~d}$ (Table 2), thus enabling the P-requirement for the Trichodesmium spp. biomass to be maintained until the DIP concentration remained above the critical DIP concentration of $9 \mathrm{nM}\left(t_{\mathrm{d}}<7 \mathrm{~d}\right)$. This indicates that a relatively high DIP concentration (DIP > $9 \mathrm{nM}$ corresponding to an in situ DIP turnover time $\mathrm{T}_{\text {DIP }}>50 \mathrm{~h}$ ) may be necessary for Trichodesmium spp. to maintain a growth rate above $0.1 \mathrm{~d}^{-1}$ (considered the minimum value because it was the lowest Trichodesmium spp. growth rate measured in the water column during all the cruises). Another condition, always observed in our study area, is a DIN:DIP < the Redfield ratio (DIN: dissolved inorganic nitrogen) which favours di-nitrogen fixing organisms (Karl et al. 2002).

\section{DISCUSSION}

According to Mulholland et al. (2002), 'There are few studies that have investigated the kinetics of nonnitrogenous nutrient uptake by Trichodesmium. In the only kinetic study published regarding $\mathrm{P}$ uptake, it was demonstrated that Trichodesmium has a low affinity for DIP (McCarthy \& Carpenter, 1979)'. However, the lowest concentration used in their inorganic $\mathrm{P}$ uptake experiment was $100 \mathrm{nM}$, at least $2 \times$ higher than the ambient DIP that they measured in the subtropical N Atlantic Ocean (between Spain and Bermuda). They went on to use a linear extrapolation from their plot (see Fig. 4, p. 79 of McCarthy \& Carpenter 1979) for the uptake rate at $50 \mathrm{nM}$, and approximated a maximum uptake rate of 1.2 pmol colony $^{-1} \mathrm{~h}^{-1}$ (see line 22, p. 80). Due to an error in units, this value was underestimated by a factor of 1000. The maximum uptake rate was in fact $1.2 \mathrm{nmol}$ colony $^{-1} \mathrm{~h}^{-1}$ which gives a very different interpretation of their results. Using the $\mathrm{C}$ colony $^{-1}$ data and an estimated C:P ratio of 100 , they calculated that Trichodesmium spp. at $1.2 \mathrm{pmol}_{\text {colony }}{ }^{-1} \mathrm{~h}^{-1}$ required $5000 \mathrm{~h}$ to double the constituent $\mathrm{P}$ (see line 28, p. 80). Using the same calculation, and the 'corrected' uptake rate of $1.2 \mathrm{nmol}$ colony $^{-1} \mathrm{~h}^{-1}$, this time is reduced to $5 \mathrm{~h}$, which gives a specific uptake rate of $0.14 \mathrm{~h}^{-1}$; a value closer to the one we observed (Table 2).

Letelier \& Karl (1998) used sinking colonies of Trichodesmium spp. at the ALOHA station in the North Pacific subtropical gyre and found an active uptake of DIP. Using a time course experiment with an initial DIP concentration of $180 \mathrm{nM}$, a concentration not encountered in the upper surface water, it was found that sinking Trichodesmium colonies were able to assimilate the equivalent of 35 to $57 \%$ of their P content from inorganic $\mathrm{P}$ over the first $12 \mathrm{~h}$ of a dark incubation. This is in accordance with the 5.0 to $8.3 \mathrm{~h}$, calculated using our results, required to obtain the same $\mathrm{P}$ content at this concentration.

Recently, Sañudo-Wilhelmy et al. (2004) and Fu et al. (2005) proposed new $K_{\mathrm{s}}$ values between 0.20 and $0.68 \mu \mathrm{M}$ for laboratory cultures of Trichodesmium IMS101 and GBRTRLI101, in agreement with our field results $\left(K_{\mathrm{s}}=0.63 \mu \mathrm{M}\right)$. New $K_{\mathrm{s}}$ estimations are largely below the $K_{\mathrm{s}}$ value of $9 \mu \mathrm{M}$ previously reported by McCarthy \& Carpenter (1979).

Our study indicates that inorganic phosphate uptake by single filaments of Trichodesmium spp. in the upper surface water may sustain Trichodesmium spp. growth when DIP > 9 nM. Thus, growth may not require uptake of dissolved organic phosphate nor entail vertical migrations. Letelier \& Karl (1998) hypothesized that the vertical migration of Trichodesmium spp. could contribute to their P-requirement. They admitted, though, that their hypothesis did not explain the large concentration of non-migratory single trichomes observed in the upper water column, unless the colony versus free trichomes morphology was a transient condition under cellular control.

Direct cross-membrane transport is known for a few DOP compounds; however, this pathway is probably minor compared with ectoenzyme hydrolysis of DOP prior to DIP uptake (Björkman \& Karl 2003). Assuming that DOP compounds are hydrolyzed outside the cells (Thingstad et al. 1996), phosphate required to create new biomass is then taken up in the form of orthophosphate only. According to this classical hypothesis, organisms compete for DIP in order to obtain their P-requirements. In this case, DIP uptake measurements correspond to the utilization of the DIP + DOP pool and remain the key process when studying $\mathrm{P}$ control on Trichodesmium spp. growth and biomass. The small differences observed during our seasonal observations in the DOP pool (Van Den Broeck et al. 2004) could indicate that it was mainly composed of refractory materials. This is not in contradiction with the rapid turnover times of a small fraction of the DOP pool. The data of McCarthy \& Carpenter (1979) show that Trichodesmium spp. has a low affinity for DIP but a high potential for utilizing phosphomonoesters (DOP). As a result, recent studies have only focused on the utilization of DOP compounds when attempting to explain Trichodesmium spp. abundance (Stihl et al. 2001, Mulholland et al. 2002). Mulholland et al. (2002) argued that DOP can represent an important P source for Trichodesmium spp. growth: however, DIP uptake was not measured. This conclusion may need to be re-examined considering the results presented here. 
The relationship between P-limited Trichodesmium spp. growth and the cellular-P quota is currently unknown (Kustka et al. 2003). Trichodesmium spp. growth is obviously related to the $\mathrm{P}$ internal quota rather than to the direct uptake of phosphate. This implies that the critical DIP availability could correspond to the end of the P-storage ability that may precede the decrease in Trichodesmium spp. growth rate.

Studies of nutrient dynamics in marine systems have begun to focus on turnover times (Benitez Nelson 2000). DIP concentrations, recently estimated by indirect methods in oligotrophic systems (Moutin et al. 2002), are often below the detection limit of the classical blue molybdenum method currently in use during oceanic cruises (30 nM) even when using the MAGIC procedure for pre-concentrating (5 nM) (Benitez Nelson 2000). DIP turnover time appears to be the most useful variable for characterizing DIP availability. The annual seasonal variations observed for DIP turnover times are plotted against seawater temperature (Fig. 2), indicating favourable and unfavourable growth conditions for Trichodesmium spp.

Large $\mathrm{T}_{\mathrm{DIP}}$ variations were observed when DIP concentrations were undetectable. $\mathrm{T}_{\text {DIP }}$ reached $4 \mathrm{~h}$ during summer, which is characteristic of extremely P-depleted areas, such as the Mediterranean Sea (Moutin et al. 2002). Summer $\mathrm{T}_{\mathrm{DIP}}$ values were lower than the $\mathrm{T}_{\text {DIP }}$ value of $48 \mathrm{~h}$ measured in the summer of 1997 at the climax station (Björkman et al. 2000). The latter station is close to the ALOHA station in the North

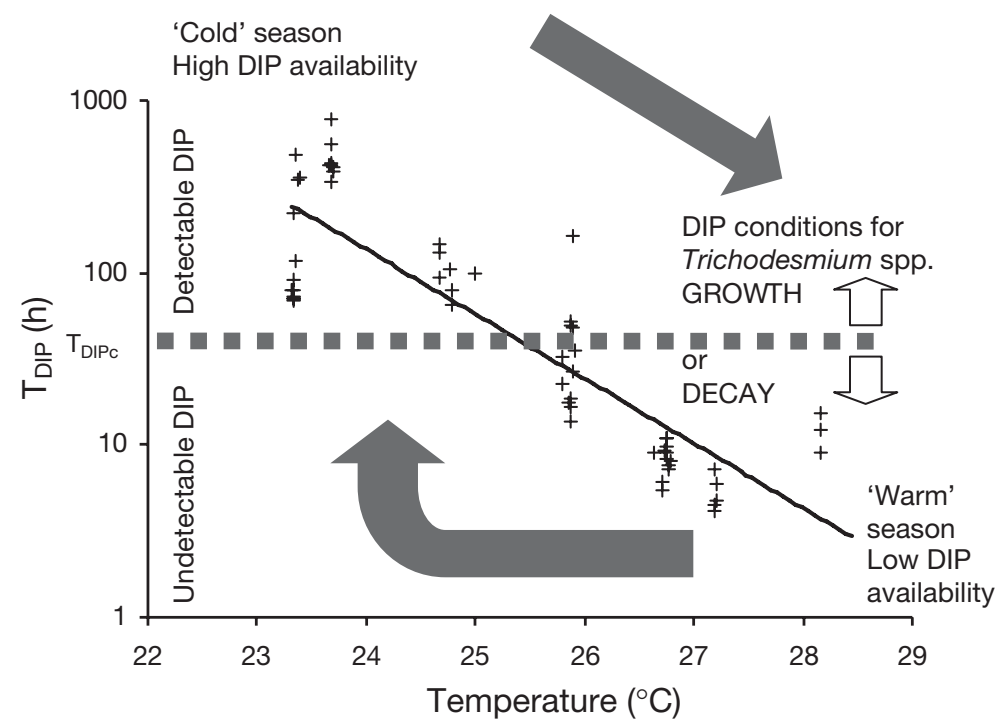

Fig. 2. Dissolved inorganic phosphate turnover times $\left(\mathrm{T}_{\mathrm{DIP}}\right)$ versus temperature measured in the mixed layer during Diapalis Cruises 1 to 6 in the SW Pacific Ocean near New Caledonia. $\mathrm{T}_{\text {DIPc }}$ corresponds to the critical DIP availability allowing (or not) Trichodesmium spp. growth. The 2 arrows show the annual cycle (rising: warm to cold season transition, descending: cold to warm season transition). The $y$-axis is logarithmic
Pacific Ocean where a shift from nitrogen to phosphate limitation was observed (Letelier \& Karl 1998). A very simple scheme which considers both the input of new phosphate from deep layers during winter mixing (homogeneous temperature around 23 to $24^{\circ} \mathrm{C}$ from the surface to the upper phosphacline), and the decrease in DIP availability corresponding to the beginning of summer stratification (temperature $>25^{\circ} \mathrm{C}$ ), could explain why most Trichodesmium spp. surface accumulations (observed between November 1998 and April 2003 in the SW subtropical Pacific Ocean, $18-25^{\circ} \mathrm{S}$ latitude; $160-174^{\circ} \mathrm{E}$ longitude) occur from November to January (Fig. 3). This observation zone is the Caledonian Economical Zone (CEZ) which was under surveillance throughout the year and entirely supervised twice a month by the French Navy (no geographical parcel was better supervised than another). Winter DIP enrichment requires a previous cooling of the surface waters, which may explain the low occurrence of Trichodesmium spp. accumulations during fall. Indeed, temperatures above $26^{\circ} \mathrm{C}$ are necessary for Trichodesmium spp. bloom development (Carpenter et al. 2004).

The monthly mean sea surface temperature was plotted for the central Chenal des loyauté station $\left(21^{\circ} 30^{\prime} \mathrm{S}\right.$ latitude; $167^{\circ} \mathrm{E}$ longitude) together with the DIP turnover times $\left(\mathrm{T}_{\mathrm{DIP}}\right)$ calculated from the relationship between $\mathrm{T}_{\mathrm{DIP}}$ and temperature $(\theta)$ measured in the mixed layer during Diapalis Cruises 1 to 6 (Fig. 2: $\left.\mathrm{T}_{\text {DIP }}=1.39 \times 10^{11} \times \mathrm{e}^{-0.86 \theta}, \mathrm{r}^{2}=0.76, \mathrm{n}=45\right)$. Mean $\mathrm{T}_{\text {DIP }}$ versus mean temperatures also displayed a good agreement between calculated and measured values. Due to the ability of Trichodesmium spp. to store phosphate, phosphate deficiency in the upper water column and therefore Trichodesmium spp. decay may be delayed. This could explain why most of the observed Trichodesmium spp. accumulation occurred over a period of $3 \mathrm{mo}$. It might also be due to geographical variations in decreasing phosphate availability. Indeed, the CEZ spread out over $800 \mathrm{~km}$ from south to north. In late summer and fall when DIP from the mixed layer was almost exhausted, the occurrence of Trichodesmium spp. accumulations was reduced. This demonstrates their poor competitiveness at very low DIP concentrations. The significance of accumulating Trichodesmium spp. at the sea surface is not well understood. It could be related to Trichodesmium spp. blooms or may be only the result of physical currents, which concentrate somewhere at the surface, the biomass being produced elsewhere in the water column. In any case, it does correspond with the end of biomass production 
SW Pacific near New Caledonia $\left(18-25^{\circ} \mathrm{S}, 160-174^{\circ} \mathrm{E}\right)$

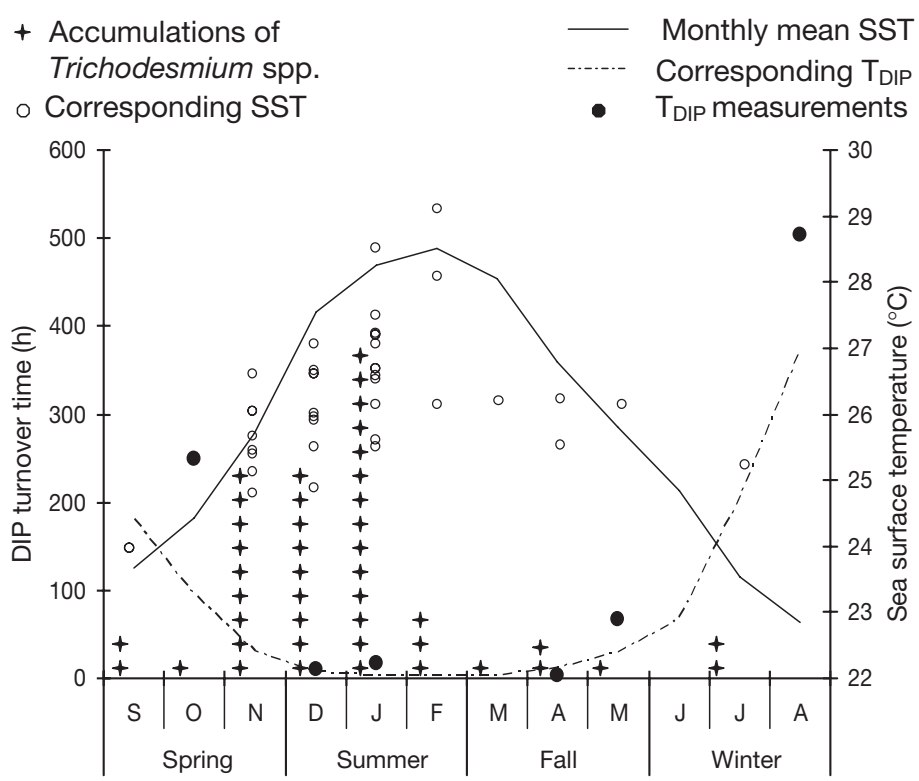

Fig. 3. Phosphate availability, sea surface temperature (SST) and occurrence of Trichodesmium spp. accumulations in surface waters of the SW Pacific Ocean near New Caledonia. +: occurrence of Trichodesmium spp. accumulations (number) between November 1998 and April 2003, from aeroplane and ship observations by the French navy in the Caledonian Economical Zone $\left(18-25^{\circ} \mathrm{S}\right.$ latitude and $160-174^{\circ} \mathrm{E}$ longitude). Left $y$-axis: dissolved inorganic phosphate (DIP) turnover time $(\mathrm{h})$. Right $y$-axis: SST $\left({ }^{\circ} \mathrm{C}\right)$ obtained at www. cdc.noaa.gov/cdc/data.noaa.oisst.v2.html at the geographical position where Trichodesmium spp. accumulations were observed (O) and at the Chenal des Loyauté station (-)

and is observed when the available DIP decreases at the sea surface. This 'bottom up' control hypothesis for the termination of the Trichodesmium 'blooms' differs from the 'top down' controls of grazers (O'Neil 1998) or by bacteriophage infections (Ohki 1999) already mentioned. Others have suggested that phosphate starvation is one of the key factors controlling Trichodesmium spp. mortality, based on laboratory experiments (Berman-Frank et al. 2004) but no direct links between P-availability and early summer sea surface Trichodesmium spp. accumulations have been previously shown. The observations of some Trichodesmium spp. accumulations, at other time periods, require different explanations. Could these observations be related to mixing events that occasionally provide phosphate from deep nutrient rich waters?

The sharp decrease of DIP availability in the early summer season could explain most of the numerous and periodic sea-surface accumulations of Trichodesmium spp. observed, without taking into account the role of iron, the other major factor controlling nitrogen fixation in the ocean (Falkowski 1997). This phosphate control may be related to a high iron availability in this area (Van den Broeck et al. 2004), as it has been suggested for the North Atlantic Ocean (Wu et al. 2001). It runs against current ideas that the Pacific Ocean is more severely iron limited (Wu et al. 2001) with the $S$ Pacific having the greatest degree of Fe limitation of diazotrophy (Behrenfeld \& Kobler 1999). Our results suggest a re-evaluation of DIP availability in oligotrophic areas where Trichodesmium spp. are common, in order to study geographical trends of nutrient limitation on $\mathrm{N}_{2}$ fixation, particularly from the west to the east South Pacific Ocean. Our results are also important in understanding how the N/P balance is controlled in the ocean. If the N-level adjusts to the P-level via nitrogen-fixation and denitrification, a model with nitrogen fixers that will be controlled by iron (Falkowski 1997) or phosphate (Tyrell 1999) would predict different ultimate controls on primary production, i.e. different responses of the ocean to global warming.

Acknowledgements. We gratefully acknowledge the many colleagues whose efforts facilitated and contributed to the results. F. T. Thingstad and T. Lefèvre are acknowledged for their suggestions on this manuscript as well as the anonymous reviewers for Nature magazine for their constructive comments on the first presentation of this work in December 2003. We wish to thank the crew of the RV 'L'Alis' for outstanding shipboard support operations. Diapalis cruises were funded by IRD, INSUE and PROOF (France-JGOFS).

\section{LITERATURE CITED}

Behrenfeld MJ, Kobler ZS (1999) Widespread iron limitation of phytoplankton in the south Pacific ocean. Nature 283: 840-843

Benitez Nelson C (2000) The biogeochemical cycling of phosphorus in marine systems. Earth-Sci Rev 51:109-135

Berman-Frank I, Bidle KD, Haramaty L, Falkowski PG (2004) The demise of the marine cyanobacterium, Trichodesmium spp., via an autocatalysed cell death pathway. Limnol Oceanogr 49:997-1005

Björkman K, Karl DM (2003) Bioavailability of dissolved organic phosphorus in the euphotic zone at station ALOHA, north Pacific subtropical gyre. Limnol Oceanogr 48(3):1049-1057

Björkman K, Thompson-Bulldis AL, Karl DM (2000) Phosphorus dynamics in the North Pacific subtropical gyre. Aquat Microb Ecol 22:185-198

Carpenter EJ, Subramaniam A, Capone DJ (2004) Biomass and primary productivity of the cyanobacterium Trichodesmium spp. in the tropical N Atlantic ocean. Deep-Sea Res I 51:173-203

Codispoti LA (1989) Phosphorus vs. nitrogen limitation of new and export production. In: Berger WH, Smetacek VS, Wefer G (eds) Productivity of the ocean: present and past. Wiley, New York, p 377-394

Dupouy C, Neveux J, Subramaniam A, Mulholland MR, Montoya JP, Campbell L, Carpenter EJ, Capone DG 
(2000) Satellite captures Trichodesmium blooms in the southwestern tropical Pacific. EOS 81:13-16

Falkowski PG (1997) Evolution of the nitrogen cycle and its influence on the biological sequestration of $\mathrm{CO}_{2}$ in the ocean. Nature 387:272-275

Fu FX, Bell PRF (2003) Factors affecting $\mathrm{N}_{2}$ fixation by the cyanobacterium Trichodesmium sp. GBRTRLI101. FEMS Microbiol Ecol 45:203-209

Fu FX, Bell PRF, Hutchins DA (2005) Phosphate uptake and growth kinetics of Trichodesmium (cyanobacteria) isolates from the North Atlantic ocean and the great barrier reef, Australia. J Phycol 41:62-73

Hillebrand H, Durselen CD, Kirschtel D, Pollingher U, Zohary $\mathrm{T}$ (1999) Biovolume calculation for pelagic and benthic microalgae. J Phycol 35:403-424

Karl DM, Michaels A, Bergman B, Capone DJ and 6 others (2002) Dinitrogen fixation in the world's oceans. Biogeochemistry 57/58:47-98

Kustka A, Carpenter EJ, Sañudo-Wilhelmy SA (2002) Iron and marine nitrogen fixation: progress and future directions. Res Microbiol 153:255-262

Kustka AB, Sañudo-Wilhelmy SA, Carpenter EJ, Capone DG, Burns J, Sunda WJ (2003) Iron requirements for dinitrogen- and ammonium-supported growth in cultures of Trichodesmium (IMS 101): comparison with nitrogen fixation rates and iron: carbon ratios of field populations. Limnol Oceanogr 48:1869-1884

Letelier RM, Karl DM (1998) Trichodesmium spp. physiology and nutrient fluxes in the North Pacific subtropical gyre. Aquat Microb Ecol 15:265-276

McCarthy JJ, Carpenter EJ (1979) Oscillatoria (Trichodesmium) thiebautii (Cyanophyta) in the general central North Atlantic Ocean. J Phycol 15:75-82

Mills MM, Ridame C, Davey M, La Roche J, Geider RJ (2004) Iron and phosphorus co-limit nitrogen fixation in the eastern tropical North Atlantic. Nature 429:292-294

Moutin T, Thingstad TF, Van Wambeke F, Marie D, Slawyk G, Raimbault P, Claustre H (2002) Does competition for nanomolar phosphate supply explain the predominance of the cyanobacterium Synechococcus? Limnol Oceanogr 47: $1562-1567$

Mulholland MR, Floge S, Carpenter EJ, Capone DJ (2002) Phosphorus dynamics in cultures and natural populations of Trichodesmium spp. Mar Ecol Prog Ser 239:45-55

Editorial responsibility: John Dolan (Contributing Editor), Villefranche-sur-Mer, France
Ohki K (1999) A possible role of temperate phage in the regulation of Trichodesmium biomass. Bull Inst Oceanogr Monaco 19:287-291

O'Neil JM (1998) The colonial cyanobacterium Trichodesmium as a physical and nutritional substrate for the harpacticoid copepod Macrosetella gracilis. J Plankton Res 20:43-59

Paasche E, Erga SR (1988) Phosphorus and nitrogen limitation of phytoplankton in the inner Oslofjord (Norway). Sarsia 73:229-243

Pujo-Pay M, Raimbault P (1994) Improvement of the wetoxidation procedure for simultaneous determination of particulate organic nitrogen and phosphorus collected on filters. Mar Ecol Prog Ser 105:203-207

Sañudo-Wilhelmy SA, Kustka AB, Gobler J, Hutchins DA and 6 others (2001) Phosphorus limitation of nitrogen fixation by Trichodesmium in the central Atlantic Ocean. Nature 411:66-69

Sañudo-Wilhelmy SA, Tovar-Sanchez A, Fu FX, Capone DG, Carpenter EJ, Hutchins DA (2004) The impact of surface adsorbed phosphorus on phytoplankton Redfield stoichiometry. Nature 432:897-901

Smayda TJ (1978) From phytoplankton to biomass. In: Sournia A (ed) Phytoplankton manual. Monographs on oceanographic methodology 6. UNESCO Publications, Paris, p 273-279

Stihl A, Sommer U, Post AF (2001) Alkaline phosphatase activities among populations of the colony-forming diazotrophic cyanobacterium Trichodesmium spp. (Cyanobacteria) in the Red Sea. J Phycol 37:310-317

Strickland JDH, Parsons TR (1972) A practical handbook of seawater analysis. Bull Fish Res Board Can 167:49-55

Thingstad TF, Dolan JR, Fuhrman J (1996) Loss rate of an oligotrophic bacterial assemblage as measured by $\mathrm{H}-3-$ thymidine and $\left(\mathrm{PO}_{4}\right)$-P-32: good agreement and nearbalance with production. Aquat Microb Ecol 10:29-36

Tyrell T (1999) The relative influences of nitrogen and phosphorus on oceanic primary production. Nature 400:525-531

Van Den Broeck N, Moutin T, Rodier M, Le Bouteiller A (2004) Seasonal variations of phosphate availability in the SW Pacific ocean near New Caledonia. Mar Ecol Prog Ser 268:1-12

Wu J, Boyle E, Sunda W, Wen LS (2001) Soluble and colloidal iron in the oligotrophic North Atlantic and North Pacific. Science 293:847-849

Submitted: February 7, 2005; Accepted: May 16, 2005

Proofs received from author(s): July 20, 2005 